Hydrol. Earth Syst. Sci., 15, 3639-3649, 2011

www.hydrol-earth-syst-sci.net/15/3639/2011/

doi:10.5194/hess-15-3639-2011

(C) Author(s) 2011. CC Attribution 3.0 License.

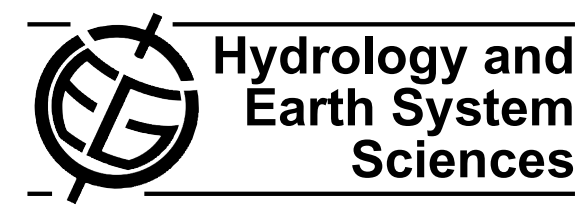

\title{
Deepwater Horizon oil spill impacts on Alabama beaches
}

\author{
J. S. Hayworth ${ }^{1}$, T. P. Clement ${ }^{1}$, and J. F. Valentine ${ }^{2}$ \\ ${ }^{1}$ Department of Civil Engineering, Auburn University, Auburn, Alabama, USA \\ ${ }^{2}$ Department of Marine Sciences, University of South Alabama, Dauphin Island Sea Laboratory, Alabama, USA
}

Received: 14 June 2011 - Published in Hydrol. Earth Syst. Sci. Discuss.: 12 July 2011

Revised: 28 October 2011 - Accepted: 17 November 2011 - Published: 1 December 2011

\begin{abstract}
From mid June 2010 to early August 2010, the white sandy beaches along Alabama's Gulf coast were inundated with crude oil discharged from the Deepwater Horizon well. The long-term consequences of this environmental catastrophe are still unfolding. Although BP has attempted to clean up some of these beaches, there still exist many unanswered questions regarding the physical, chemical, and ecological state of the oil contaminated beach system. In this paper, we present our understanding of what is known and known to be unknown with regard to the current state of Alabama's beaches in the aftermath of the Deepwater Horizon disaster. Motivated by our observations of the evolving distribution of oil in Alabama's beaches and BP's clean-up activities, we offer our thoughts on the lessons learned from this oil spill disaster.
\end{abstract}

\section{Introduction}

"There are known knowns; there are things we know we know. We also know there are known unknowns; that is to say we know there are some things we do not know. But there are also unknown unknowns - the ones we don't know we don't know." (Former United States Secretary of Defense Donald Rumsfeld)

On 17 December 2010, the Operational Science Advisory Team (OSAT), under the auspices of the Deepwater Horizon accident response Unified Area Command (UAC), released a report entitled Summary Report for Sub-Sea and Sub-Surface Oil and Dispersant Detection: Sampling and

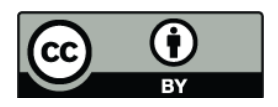

Correspondence to: T. P. Clement (clemept@auburn.edu)
Monitoring (Operational Science Advisory Team (OSAT), 2010). The stated purpose of this report was to provide federal on-scene coordinators for the Deepwater Horizon accident with sufficient information to document the presence (or absence) of sub-surface and sub-sea oil and dispersants which are amenable to removal actions under the provisions of the Clean Water Act, the Oil Pollution Act of 1990, and the National Oil and Hazardous Substances Pollution Contingency Plan. In his cover letter, the Federal On-Scene Coordinator (Rear Admiral Paul F. Zukunft, US Coast Guard) noted that the "sub-sea and sub-surface monitoring assessment effort was comprehensive and culminated in a rigorous set of analytical data." Key findings from the report indicate that the presence of actionable oil (i.e., oil that was amenable to removal) was negligible.

Directly following release of the OSAT report, BP issued a press release (BP, 2011) stating in part "the scientific evidence in this report is consistent with our observations that the beaches are safe, the water is safe, and the seafood is safe." The authors of the OSAT report made no such definitive claims about safety. The OSAT report emphasized that "assessing non-response questions, including quantitative estimates of remaining oil and the long-term environmental impacts of the Deepwater Horizon oil spill, are beyond the scope of this report." The report also noted that near shore assessments (i.e., waters inshore of the 3 nautical mile state waters boundary) were incomplete and would be addressed in a follow-up report (OSAT-2).

On 10 February 2011, the OSAT-2 report was released to the public (Operational Science Advisory Team (OSAT-2), 2011). This report (entitled Summary Report for Fate and Effects of Remnant Oil in the Beach System) attempts to address important information gaps in the December 2010 OSAT report; however, careful review of this document shows that it

Published by Copernicus Publications on behalf of the European Geosciences Union. 


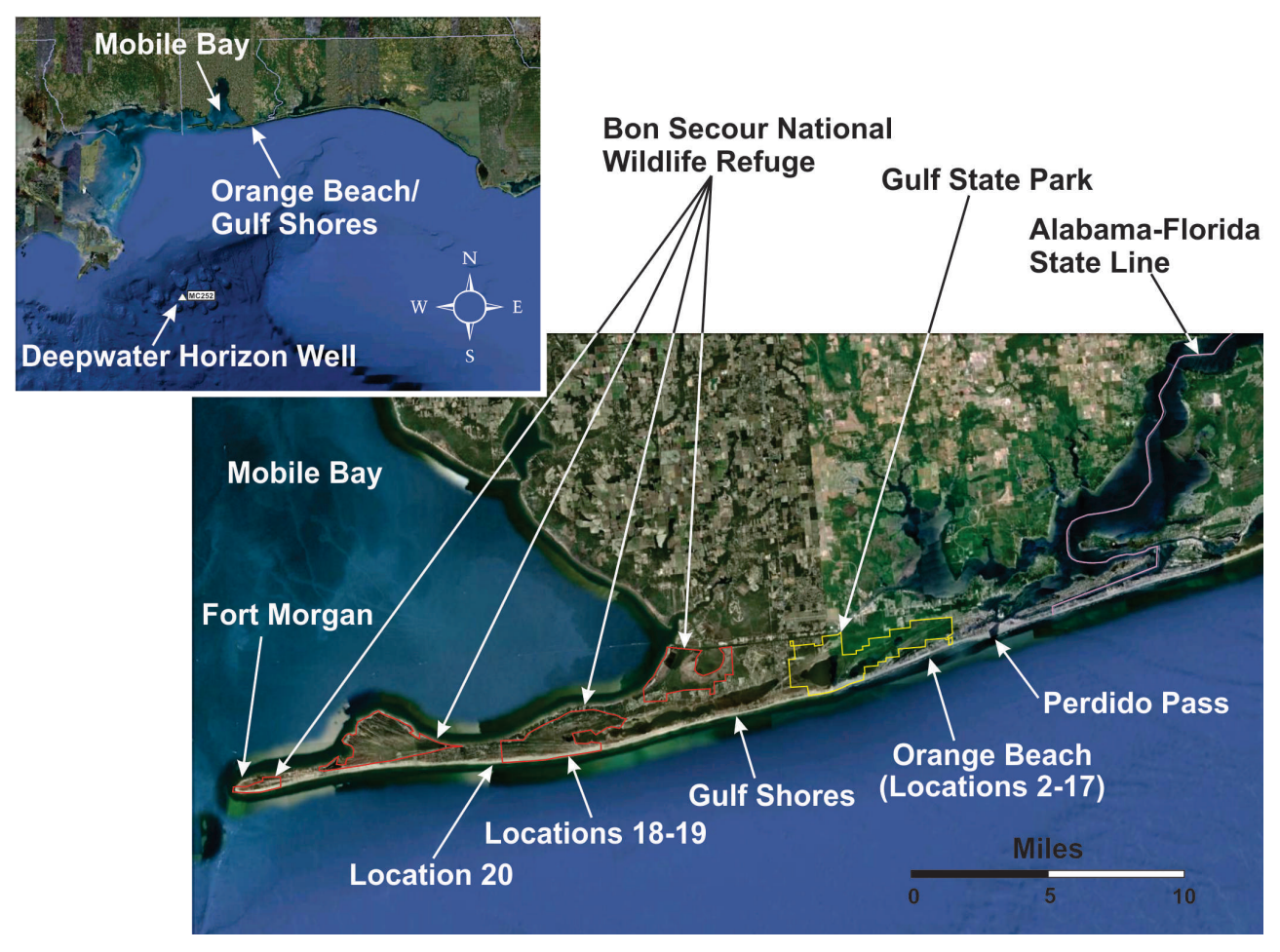

Fig. 1. Alabama's main Gulf-facing sandy beach shoreline (and sampling locations from OSAT database discussed in paper).

provides little supporting data documenting the effectiveness of the beach cleanup activities or the long-term fate of remnant oil remaining in the beach system. The report states that all bulk oil deposits in the intertidal zone, on all impacted beaches, were (or are) in the process of being removed. Our field observations (discussed in this paper) indicate that this may not be completely justified.

The objective of this paper is to report our observations to-date on the current state of beaches in Alabama and summarize our understanding of what is known, what is known to be unknown, and what is truly unknown regarding the Deepwater Horizon impacts on the near shore environment.

\section{What do we know now?}

"Reality must take precedence over public relations, for nature cannot be fooled." (Richard Feynman)

Alabama has approximately 60 miles of shoreline facing the Gulf of Mexico, and many more miles of tidallyinfluenced coastal bays, rivers, and bayous. From an economic, aesthetic, and ecosystem services perspective, the roughly 30 miles of shoreline from the Alabama-Florida State line to Mobile Bay is priceless (Fig. 1). This stretch of shoreline forms the southern border of the Alabama coastal communities of Orange Beach and Gulf Shores, and is similar in appearance to the Panhandle beaches of Florida (from Pensacola east to Panama City Beach). Additionally, an Al- abama state park (Gulf State Park) and a federal wildlife refuge (Bon Secour National Wildlife Refuge (NWR)) are located along this shoreline. Miles of undisturbed beach/dune ecosystems provide habitat for a wide variety of plants and animals, some of which are endangered (i.e., the Alabama Beach Mouse). The beaches serve as nesting sites for green, loggerhead, and Kemp's Ridley sea turtles, and as habitat for non-game birds migrating south in the fall and north in the spring as well. More than 400 species of birds have been identified and banded at Bon Secour NWR (Caudill and Henderson, 2005). The economic value of the beaches to the City's of Orange Beach and Gulf Shores, and to the State of Alabama, is incredibly significant. In 2008, more than 2 million people visited the Alabama Gulf Coast region, spending more than 3 billion dollars and directly supporting more than 59000 jobs. This represents approximately $35 \%$ of the total jobs, revenue, and visitors for the State of Alabama (2009).

Most of what we know about the impacts of Deepwater Horizon-related oil on Alabama's beaches is based on the physical distribution of remnant oil. Starting around 9 June 2010, Deepwater Horizon-related oil began washing up onto the Orange Beach-Gulf Shores shoreline, continuing until about mid-July, 2010 (Fig. 2). During this time period, average air temperatures ranged between $73^{\circ} \mathrm{F}-85^{\circ} \mathrm{F}$, and average near-shore water temperatures ranged between $82^{\circ} \mathrm{F}-84^{\circ} \mathrm{F}$. Tidal motion is diurnal along the stretch of $\mathrm{Al}-$ abama beaches, with a normal tidal range of approximately $1-2 \mathrm{ft}$. Additionally, three spring tides occurred during this 


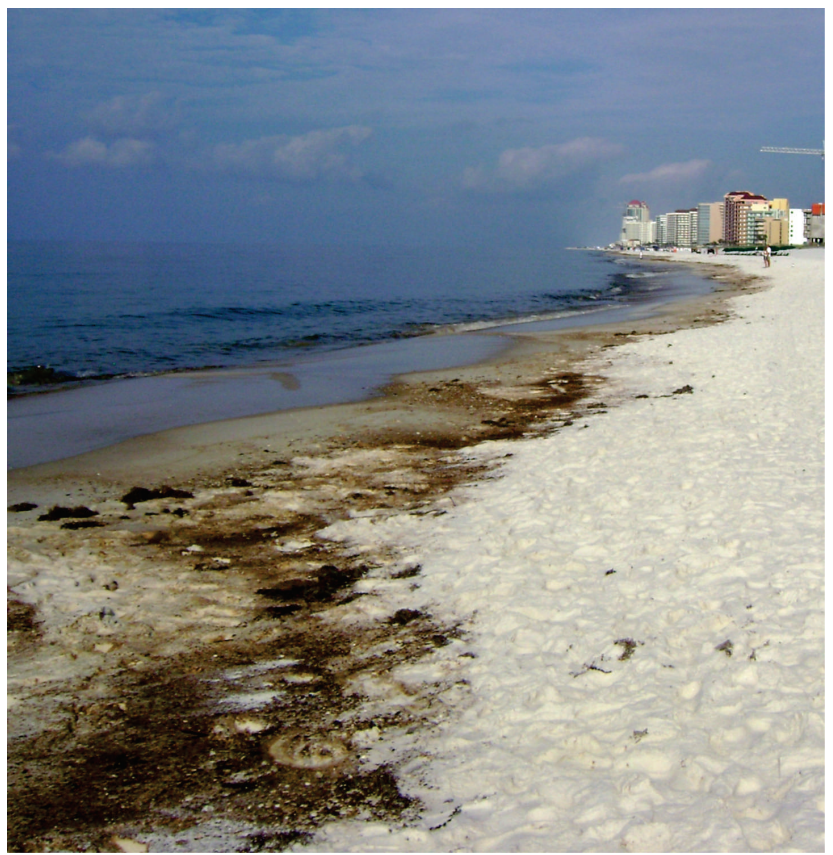

Fig. 2. Deepwater Horizon-related oil on Orange Beach, Alabama, 24 June 2010.

time period, as well as Tropical Depression Bonnie (2325 July 2010). Attempts were made in near-shore waters to restrict oil from reaching the shoreline using floating oil containment booms; however, these attempts were largely ineffective due to both normal and storm-related waves on oil-capturing efficiency (e.g., Filosa, 2010). Remnant oil (primarily tar balls) continues to wash onto the beach today, with increased intensity and frequency during storm events. Hundreds of volunteers and BP-contractors attempted to immediately remove beached oil during, and in the days following these oiling events. Natural movement of sand and water through the beach system continues to transform and re-distribute this mobile remnant oil within the system. As of November 2011, one can still encounter mobile remnant oil in varied states of weathering, buried at different depths in the near-shore beaches (Fig. 3).

In addition to the transformation and re-distribution of the mobile remnant oil, there exists an unknown amount of relatively immobile remnant oil. This immobile remnant oil exists primarily in the form of large, discontinuous mats buried (from centimeters to nearly a meter below the existing sand surface), in unknown offshore locations and in the beach from the intertidal zone to the start of the backshore dunes. These mats range in thickness from a few millimeters to several centimeters and likely represent a substantial amount of the oil that reached the Alabama shoreline from June to July of 2010 .

Towards the end of March 2011, BP completed their active beach cleanup strategy for restoring the amenity beaches of Orange Beach and Gulf Shores. The beach cleanup approach involved excavation of oil-contaminated sand, mechanical sieving of this sand to remove remnant oil, and replacement of cleaned sieved sand into the excavation area (Fig. 4; Hayworth and Clement, 2011). While this mechanical clean-up strategy successfully removed some large pieces of well-consolidated remnant oil, it also dispersed smaller particles of remnant oil over a larger volume of sand. From the perspective of decreasing the potential risk of exposure to large fragments of remnant oil and potentially increasing net mass-transfer/degradation rates for semi-volatile organic constituents remaining in the remnant oil, this approach may prove beneficial. However, it is also true that tiny fragments of remnant oil are now more widely distributed and homogenized over a larger volume of beach sand.

Immediately following the Deepwater Horizon accident, and continuing to this day, various groups mobilized to conduct environmental sampling and analysis. The goals of these groups, the types of samples collected, the methods used to collect samples, and the types and methods of sample analyses varied greatly. We note here that our goal is not to critique any of these groups. Viewed in the context of the event, the sense of urgency at the time, the fear of ecological and economic disaster, the lack of guidance for decision-makers, and the flow of information and disinformation combined to create much confusion. With respect to Alabama beaches, many decisions associated with environmental sampling (at least in the days immediately following the accident) were guided by common sense and intuition. It was recognized by some groups that having an idea of the pre-oil impact state of the beaches, with respect to oil-related chemical constituents, would be useful for comparison to post-impact data. These groups included law firms eyeing future cases, the municipalities of Orange Beach and Gulf Shores, state and federal agencies with varied interests and requirements, not-for-profit environmental groups, academic researchers, and private citizens. As time passed and as the oil impacts were realized, many of these groups continued to conduct their independent sampling strategies. Today, the end result is a dataset comprised of public and private accumulations of various types of samples and associated results, varying in representativeness and quality.

The first OSAT report (Operational Science Advisory Team (OSAT), 2010) was built upon an assessment of a large database of observational, semi-quantitative, and quantitative analytical results. This database included aqueous and sediment samples from many sampling locations ranging from the deep water of the Gulf to the shoreline wetlands, estuaries, and beaches of the northern GOM. Within this database a small subset of sediment samples (approximately 94) were collected from locations within the vicinity of the Alabama shoreline from Perdido Pass to Fort Morgan (both onshore and offshore; Fig. 1). If only unqualified positive detections of polycyclic aromatic hydrocarbons (PAHs) within this small subset are considered (that is, positive PAH detections 

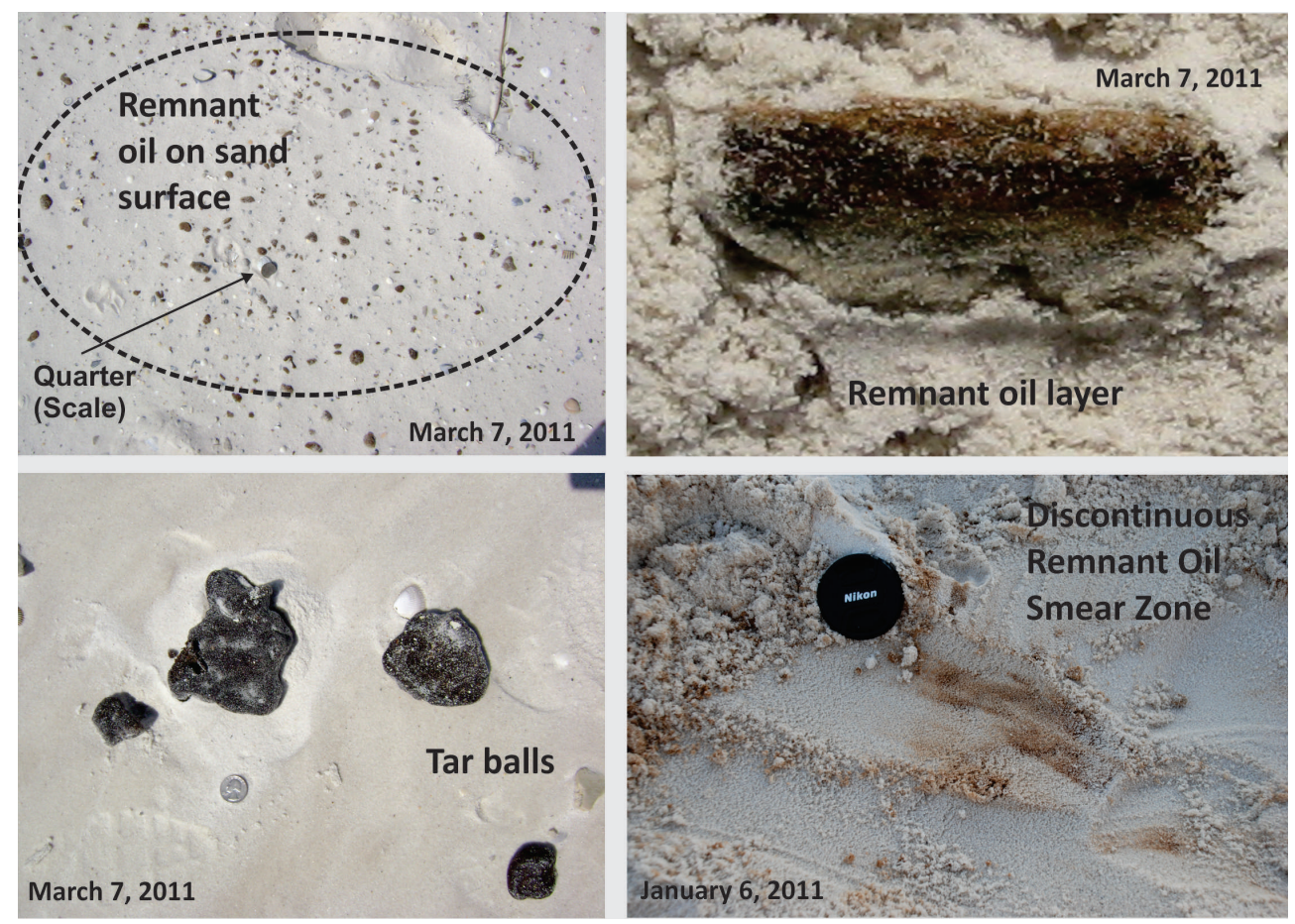

Fig. 3. Examples of remnant oil encountered along Alabama's sandy beaches.

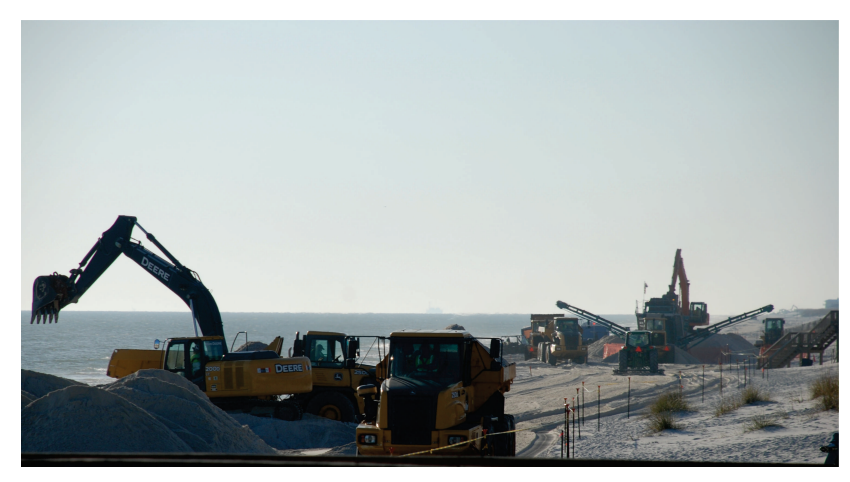

Fig. 4. BP's Operation Deep Clean along Alabama's sandy coastline, January 2011.

with no laboratory-determined quality issues) from the larger OSAT database, only 20 locations representing Alabama's beaches can be identified. Of these, 19 locations are onshore sampling sites which are shown in Fig. 5. All samples from these 19 locations were collected at the sand surface. With the exception of locations 10 and 18-20, multiple samples were collected at each location. With the exception of the single sample collected at location 18 , all samples were collected between 3 October 2010 and 17 October 2010.

Figure 6 provides a comparison of total PAHs in samples collected at all shoreline locations with the exception of location 18 (Fig. 5). Location 18 is left out of Fig. 6 because the reported total PAH values were two orders of magnitude greater than the next largest value $(33,820 \mathrm{ppb})$; the reason for this apparent anomaly will be discussed later. When Figs. 5 and 6 are considered together, it is clear that these locations do not represent the entire beach system. This conclusion is valid even though the locations shown are limited to unqualified PAH detections. The variation among samples collected at the same location, the variation between samples collected from different (but nearby) locations, and our own physical observation of these beaches suggest that the "true" distribution of remnant oil (having detectable PAH concentrations) cannot be estimated from this dataset.

With the exception of the single sample collected at location 18, all analyses summarized in Fig. 6 were limited to the 16 PAH compounds identified by the US EPA as priority pollutants (Keith and Telliard, 1979). These un-substituted (or parent) PAHs comprise a small portion of the numerous alkyl-substituted PAHs commonly found in raw crude oil (Blumer, 1976). There is evidence that alkylated PAHs are more recalcitrant in the environment and can be more toxic to certain organisms than non-alkylated PAHs (Boese et al., 1998; Ott et al., 1978; Uno et al., 2010). The sample from location 18 was collected in July 2010, whereas samples from the other locations along the shoreline were collected in October 2010. Thus, the large total PAH value for the sample at location 18 is potentially a result of both the time of sampling (closer to the onset of the oiling events) and the use of more comprehensive laboratory analysis procedures that included alkylated PAHs. An additional potential reason for 


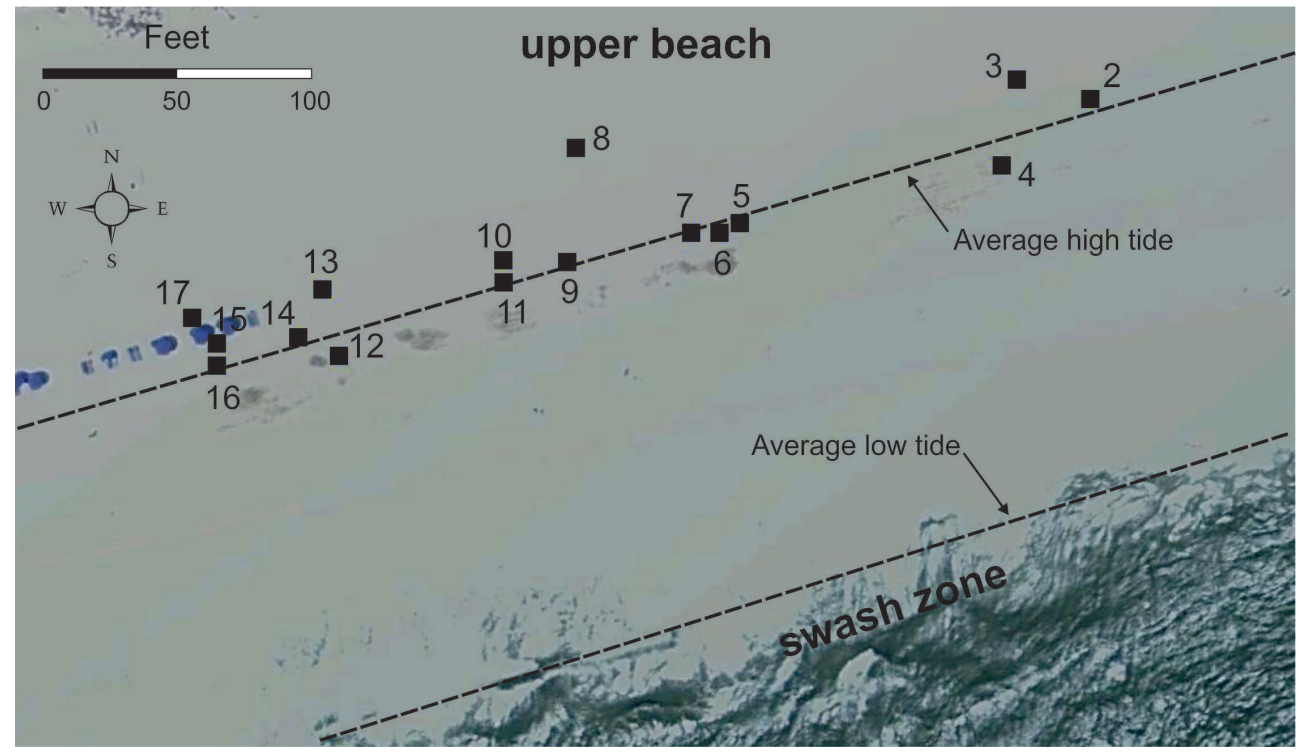

Fig. 5. OSAT sampling locations 2-17 along Alabama's beaches where unqualified total PAHs were observed (see Fig. 1 also).

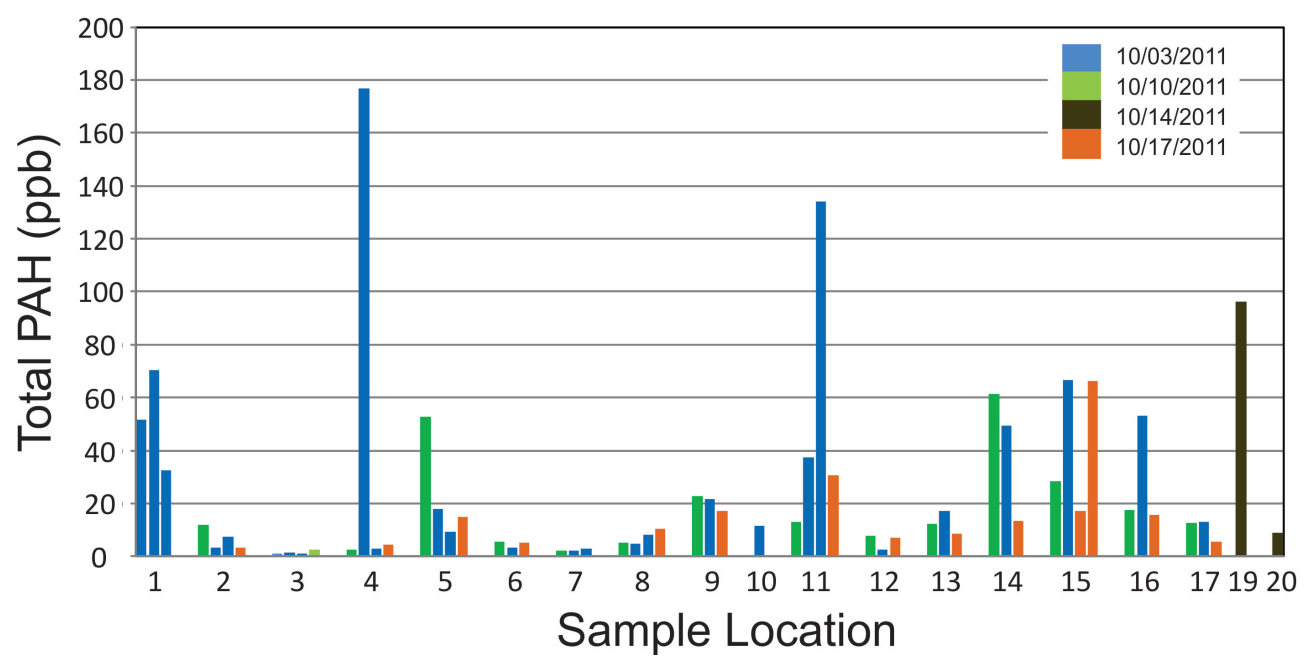

Fig. 6. Comparison of total PAHs in samples collected at shoreline locations shown in Fig. 6 (with the exception of location 18; from the OSAT database).

this could be related to sample collection methodology (i.e., inclusion of a large amount of PAH-bearing remnant oil in sample 18 relative to other samples). Since no information on sampling methodology (including sample size and collection) is included in the OSAT report, it is not possible to confirm or refute this possibility; however, this could also explain much of the variation in total PAHs observed at other sampling locations.

There is evidence that remnant oil still (as of November 2011) exists just offshore of Alabama's beaches. The OSAT-2 report (Operational Science Advisory Team (OSAT2), 2011) refers to this remnant oil as "submerged oil mats" or SOM, and states that "oil mats that have been identified were excavated and removed; however, due to the transient nature of the mats some pieces may still exist in the environment." Our observations indicate that the presence of submerged mats off Gulf Coast beaches may be more prevalent than the OSAT-2 report suggests. For the most part, these offshore submerged mats have been detected between the shoreline and the long-shore sandbar (Fig. 7). For example, the offshore submerged mat samples shown in Fig. 6 were collected off Orange Beach, Alabama on 7 March 2011, 24 days after the OSAT-2 report was released. As of November 2011, BP contractors have continued to attempt to locate 


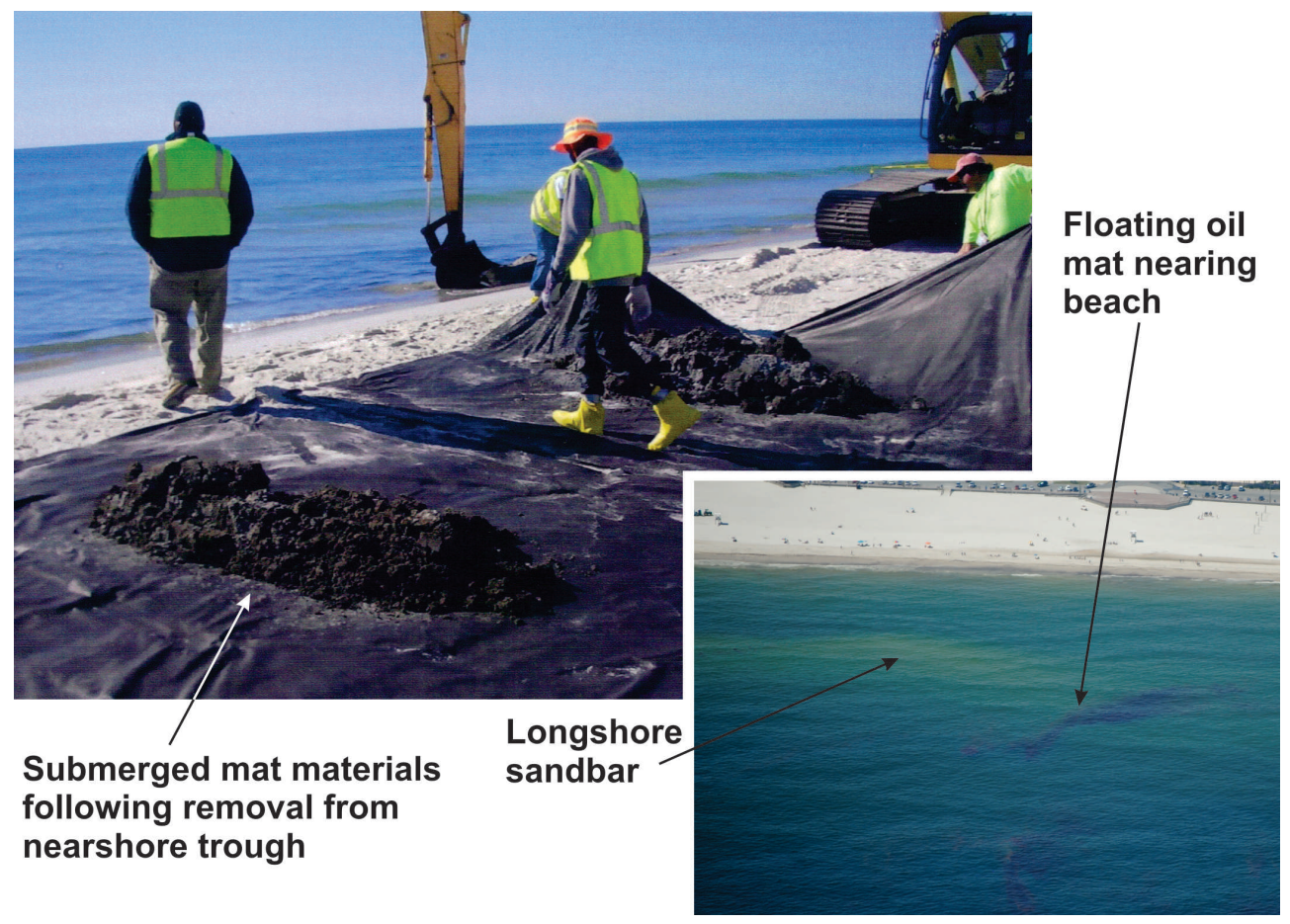

Fig. 7. Floating oil mat approaching Alabama beach, and submerged mat materials recovered from trough between longshore sandbar and shoreline.

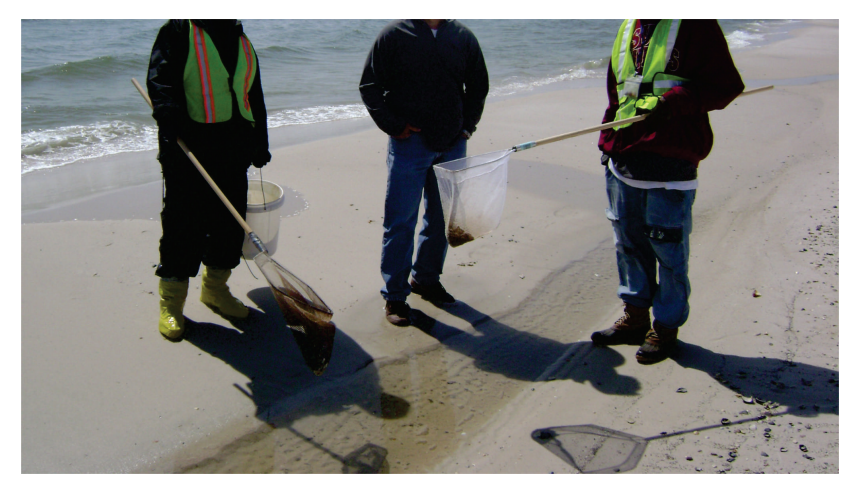

Fig. 8. BP contractors with hand nets patrolling the beach in search of tar balls, Gulf Shores, Alabama (14 March 2011).

and remove submerged mats along Alabama's shoreline; however, to date this effort has been primarily limited to the nearshore trough between the shoreline and the longshore sandbar. More recently, our team was involved in an excavation effort on 24 September 2011 and found buried oil at about $30 \mathrm{~m}$ away from the shoreline near Lagoon Pass, in Gulf Shores, Alabama. The techniques being employed to locate submerged mats are mostly dependent on indirect evidence and visual identification. Indirect evidence is provided by tar balls washing up on the beach. On a daily basis, BP contractors with hand nets (Fig. 8) patrol the shoreline picking up tar balls which are continuously washing onto the beach. Areas particularly high in tar balls are considered indirect evidence of the presence of offshore mats. Visual identification of submerged tar mats are also being made by local citizens and BP contractors from the shoreline and from boats. In turbid shallow water this is a challenging task; moreover, these mats are continually buried and uncovered by mobile sand and in deeper waters the problems are further magnified.

We have observed that submerged mat materials removed from the water range in thickness from a few millimeters to several centimeters (Fig. 7). The OSAT-2 report (Operational Science Advisory Team (OSAT-2), 2011) includes an assessment of the relative amounts of sand and remnant oil in submerged mat samples and noted that at Bon Secour NWR, this ratio is $89.3 \%$ sand and $10.7 \%$ oil. In our laboratory, we separated sand/oil fractions from several tar mat samples collected on Alabama beaches, by sequentially extracting the oil fractions into dichloromethane and drying the remaining inorganic sand and shell materials. Our laboratory data indicate that the sand content in these mats ranges from $70 \%$ to $90 \%$. Although not mentioned in the OSAT-2 report, the relatively high percentage of sand in submerged mats provides a basis for estimating the potential scale of the submerged mat problem. Roughly, for every $1 \mathrm{~kg}$ of oil trapped offshore, up to $10 \mathrm{~kg}$ of submerged mat can be formed based on the sandto-oil ratios measured in our laboratory. Additionally, the 
high sand fraction provides increased mat density and structural stability (in their submerged state), making them more recalcitrant.

To summarize what we know regarding the impact of Deepwater Horizon-related oil on Alabama's beaches: the beaches were heavily inundated by Deepwater Horizon oil between early June and late July 2010 . We also know that remnant oil is still present in the beach system, some of which is relatively mobile (due to cleaning operations and natural beach dynamics), and some which is less mobile as a result of its deposition history (submerged mats). We also know that the distribution of this remnant oil is changing with time and is likely to continue to change as a result of natural coastal processes and cleanup activities. As Hayworth and Clement (2011) noted, while BP's deep cleaning strategy has removed a considerable amount of buried oil from amenity beaches, it has also inadvertently mobilized unknown amounts of remnant oil as tiny fragments and distributed these fragments over a larger beach volume. With respect to remnant oil chemistry, we know that a sizable but disparate database of remnant oil chemistry exists, gathered primarily between June-October 2010. However, this database is insufficient to characterize actual distribution and chemical evolution of remnant oil in the beach system.

\section{What we know we don't know}

\section{"Real knowledge is to know the extent of one's ignorance." (Confucius)}

What we know we don't know regarding the impact of Deepwater Horizon-related oil on Alabama's beaches is considerable. We don't know with any certainty how much oil (in its various forms) actually impacted the beaches, and how much continues to impact the beaches today. We also have very little idea of how much oil has been removed from the beaches since it first began arriving on the shoreline. With respect to the amount of oil removed from the beaches, this information is closely held by BP and the federal government in anticipation of legal actions. With regard to the physical distribution of remnant oil residing within the beach system, we don't know how much remnant oil exists or how it is distributed at any given moment in time. Additionally, the effects of BP's "Operation Deep Clean" on the distribution and chemical evolution of remnant oil in cleaned beaches, and on the larger beach ecosystem, are also unknown.

The actual amount and distribution of submerged oil mats off Alabama's beaches is also unknown. We know little about the physical and chemical characteristics of these submerged mats, including their distribution, morphology, chemistry, and their potential to impact the beach. This is especially true for mats on the Gulf side of the longshore sandbar and extending into the deeper waters of the Continental Shelf. Our observations of submerged mat assessments and removal operations suggest that the amount of remnant oil recovered from identified submerged mats may be a small fraction of what actually exists offshore.

Figure 9 compares selected PAH constituents in a tar mat sample collected from the trough between the beach and the longshore sandbar off Orange Beach, Alabama on 7 March 2011 (Fig. 7) with the same PAH constituents in MC252 raw crude oil (i.e., crude oil from the Deepwater Horizon well). Analyses of both the tar mat and raw crude oil samples were performed by a commercial laboratory using EPA standard method 8270C/D selective ion monitoring (SIM) (EPA, 2007). This figure reiterates the point made earlier regarding the recalcitrance of alkylated PAHs: the majority of the alkylated PAHs observed in the tar mat sample are comparable to those observed in the un-weathered MC252 raw crude oil. This is remarkable, considering the provenance of the tar mat (oil discharged 1.5 miles below the ocean surface, over 100 miles away from the Alabama shoreline, nearly a year of unimpeded weathering, and exposure to dispersants. There is evidence from past oil spills that submerged mats can sequester relatively un-weathered oil within their interior for extended periods of time (Owens et al., 1999; Vandermeulen and Singh, 1994). For example, submerged mats formed as a result of the Arrow spill in Nova Scotia in 1970, although exhibiting a highly weathered exterior, were found to contain oil within their interior that was nearly identical to the composition of original spilled oil $20 \mathrm{yr}$ prior (Vandermeulen and Singh, 1994). Based on Fig. 9 and past research, it is not unreasonable to suspect that submerged mats along Alabama's beaches could serve as long-term sources of remnant oil and PAHs to the beach ecosystem.

We know very little about the chemical evolution of remnant oil as it weathers in the beach system. The existing analytical dataset is not representative of the beach system due to the scarcity of data, the variability in results, and the lack of alkylated PAH analyses. We note that the OSAT report (Operational Science Advisory Team (OSAT), 2010) acknowledges the limitations of analyzing only 16 parent PAHs, and addresses this by using alkylated multipliers to account for unmeasured alkyl compounds. Although this approach is useful as a means of more accurately estimating total PAH values, it is also not without limitations. The multipliers are based on the analysis of a single Deepwater Horizon-related tar ball collected on Dauphin Island, bolstered by published data from the Exxon Valdez spill .(Operational Science Advisory Team (OSAT), 2010). This approach becomes less viable for parent PAH concentrations at or near the analytical method detection limit: in these cases, the use of multipliers may under-report true alkylated PAH concentrations. An extreme example of this is when a parent PAH is reported to be below method detection limits. In this case, the alkylated homologs of that parent PAH will also be reported as undetected (Operational Science Advisory Team (OSAT), 2010). It may be that a detailed analysis of alkylated PAHs would 


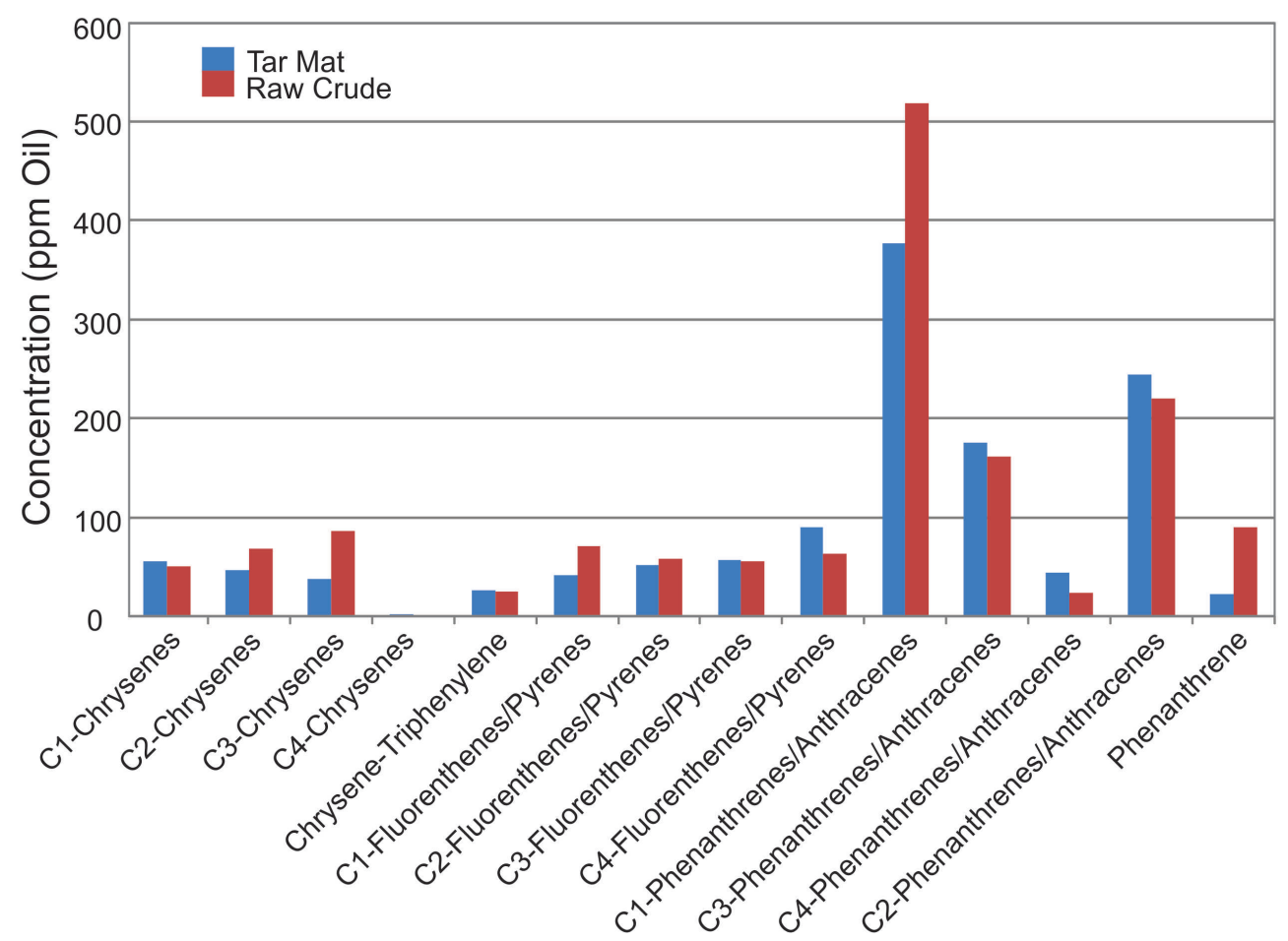

Fig. 9. Comparison of selected alkylated and non-alkylated PAHs observed in submerged tar mat sample collected off Orange Beach, Alabama (7 March 2010) and un-weathered MC252 raw crude oil.

alter the prevailing conceptual model of the beach with respect to the degree of PAH contamination.

The significance of these unknowns is clear: whatever the physical distribution and chemical evolution of remnant oil observed at a moment in time, these observations are transient in dynamic beach systems. One can imagine a scenario where relatively un-weathered remnant oil (with respect to PAHs) is periodically mobilized from offshore storage and mixed into the beach system as a result of normal or stormrelated hydrodynamics. Since we have no real measure of the amount of available offshore remnant oil and because we do not understand how the physical and chemical characteristics of the oil are changing with time, it is not possible to predict the magnitude, nor the duration of future re-depositional events.

Perhaps the most unknown of the known unknowns is the evolution of the beach ecosystem due to the presence and persistence of remnant oil. We previously discussed the uncertainty in spatial and temporal distribution of remnant oil present in both onshore and offshore environments, and the uncertainty with regard to the physical and chemical evolution of remnant oil in the beach system. Contributing to this uncertainty is our understanding of beach ecosystem impacts and the rate of recovery of the impacted system. Components of the ecosystem of major importance to humans, such as fisheries and amenity beaches, appear to recover relatively quickly depending on the magnitude and duration of oil impacts and on how aggressive and effective oil cleanup has been (Page et al., 1989; Sell et al., 1995; Kingston et al., 1995; Hoff and Shigenaka, 1999; Kingston, 2002). In these cases, the recovery process is simply assessed by the absence of remnant oil and the return of economically important fisheries to their pre-oil spill levels. Impact to, and recovery of the larger biota is much more difficult to define and assess. With respect to the near shore benthic ecosystem (perhaps the most sensitive component of the larger beach ecosystem), published past studies were conducted within the first days, weeks, or months following a spill and hence may be biased towards acute impacts. Very few studies considering ecosystem impacts and recovery have focused on the long-term, chronic, effects on the ecosystem; a much smaller subset of these have focused on the near shore and sandy beach environments. These studies have observed that recovery of benthic organisms is slower than that for more mobile and/or transitory organisms, and is dependent on the characteristics of the benthic community and the degree to which it has and continues to be impacted (Elmgren et al., 1983; Baker et al., 1990; Baker, 1991; Kingston et al., 1997; Dauvin, 1998; Kingston, 2002). Importantly, depending on the timing and severity of the event, it has been observed that the recovered benthic community will be different from its preimpact state. This is because those organisms most tolerant to oil impacts are usually the first to re-colonize an impacted area, taking advantage of the ecological niches opened by 
the death of less oil-tolerant organisms (Elmgren et al., 1983; Baker et al., 1990; Kingston et al., 1997; Dauvin, 1998). If subtidal benthic ecosystem recovery is defined as a return to pre-impact total productivity and biomass, then recovery may appear to occur relatively quickly; however, from perspective of community structure, recovery may be substantially delayed. Consider as an example the 1978 Amoco Cadiz oil spill, which killed many benthic organisms, including the numerically dominant amphipod Ampelisca (Vandermeulen and Singh, 1994). Being particularly sensitive to the effects of the oil, this crustacean did not recover to its prespill population density for almost a decade. Other, more robust organisms filled Ampelisca's vacated niche as indicated by the relatively rapid (approximately $2 \mathrm{yr}$ ) return to pre-spill total biomass and productivity (Vandermeulen and Singh, 1994).

What does this mean with respect to the recovery of Alabama's beach ecosystem? We cannot be certain exactly how the beach ecosystem, which was directly and indirectly impacted by the Deepwater Horizon oil spill, will evolve in the future. However based on historical lessons discussed above, we can be reasonably certain that the beach ecosystem will change. Whether these changes are benign or serious from a long-term ecosystem perspective will be determined only after careful studies are conducted over longer time frames.

Another source of known unknowns is related to the very simple fact that Alabama's beaches are naturally low in organic carbon content. The carbon content of the beach has been, and likely will continue to be increased by remnant oil. This particular fact, though easy to overlook when focusing on remnant oil chemical evolution and the resulting ecosystem response, could be important when it is recognized that many anthropogenic contaminants and human and ecosystem pathogens have an affinity for organic carbon and can use it as a transient niche and/or as a substrate to support their life cycles (Boehm, 1984; Fowler, 1990; Swartz et al., 1994; Hong et al., 1995; Rakocinski et al., 2000; Halliday and Gast, 2011). Thus, it is possible that contaminants and/or pathogens that normally would pass through a beach system relatively rapidly might reside in the system over a longer time period simply due to the presence of remnant oil. Whether such increases are sufficient to produce concomitant changes that eventually lead to human and/or ecological health issues, or if such changes produce other unforeseen (and potentially beneficial) outcomes, is unknown.

Two additional known unknowns important with respect to Alabama's beaches are public perception and economic health. These concerns are related: the coastal communities of Orange Beach and Gulf Shores are popular tourist destinations and to a large degree their economies are based on the image of white sandy beaches, clear blue waters, and abundant fresh seafood. Unfortunately the major impact from an economic perspective to these communities is directly related to media coverage in the months following the Deepwater Horizon accident. Whether real or perceived, the end result was much the same: the livelihoods of many innocent people were negatively impacted as a result of the accident. What is unknown is whether this perception will continue into the future. Here BP, the affected coastal communities, and the state and federal governments all share common ground in desiring this perception to change. It is important that careful, unbiased scientific studies be performed to systematically unravel reality from speculation. This will provide a clearer path towards economic recovery for the affected communities and guidance in handling future oil spills.

\section{What we don't know we don't know}

"The learning and knowledge that we have, is, at the most, but little compared with that of which we are ignorant." (Plato)

What we don't know we don't know is by definition, impossible to determine. These unknown unknowns can be broadly categorized as: (1) things we are unaware of, and (2) things we think we understand but actually we do not. There is not much that can be done with things we are unaware of, except adapt our ideas to accommodate them once they move into the realm of the known or known unknown. Things we think we know but actually do not mostly arise from interpreting incomplete information in improper ways. One thing we can be certain of: unknown unknowns exist and many will reveal themselves over the course of time. Achieving such revelations is one of the main objectives of scientific research.

\section{Lessons learned and recommendations for the future}

"Those that fail to learn from history are doomed to repeat it." (Sir Winston Churchill)

In this paper we have attempted to identify what is known and unknown with respect to the Deepwater Horizon's impact on Alabama's beaches. We can learn from this information by asking the philosophical question: what should we do now to protect against the next Deepwater Horizonlike event? This is not the first time this question has been asked after an oil spill. For example, Paine et al. (1996) reviewed lessons learned after the Exxon Valdez disaster; unfortunately, it appears many of these lessons were not learned as well as they could have been. Since oil spills occur and unfold in unique ways, it is certainly true that no two such events will result in exactly the same impacts. Regardless, there are some obvious actions which could be proposed today. It is clear in hindsight that a master sampling and analysis plan for post-spill assessment should be developed as a part of any oil spill response plan. This would help avoid many of the data uncertainty problems noted here. It is also clear that approaches for preparing sandy beaches for oil impacts, and for dealing with post-impact restoration are limited. Detailed technical assessment of the cleanup methods 
used by BP along Alabama's beaches is warranted to determine their efficacy and to identify additional technological approaches. Another area worthy of technological development is the detection and removal of submerged oil mats; the approaches being used today are time and labor intensive, and limited in effectiveness. Baseline assessment of organisms typically inhabiting Gulf Coast sandy beaches and their sensitivity and response to oil impacts is also an important area of study. This a priori knowledge could provide a means of quantifying both acute and chronic ecological impacts from future spills through post-spill monitoring. Certainly, other actions which should be undertaken will be identified as we continue to understand the true impacts of the Deepwater Horizon event.

Acknowledgements. We thank Professor Joel Melville for his helpful comments. This research was made possible, in part, by a grant from the BP Gulf of Mexico Research Initiative, a research instrumentation development grant from National Science Foundation, and by a grant from the City of Orange Beach, Alabama.

Edited by: M. Sivapalan

\section{References}

Baker, J. M.: Guidelines on the Biological Impact of Oil Pollution, IPEICA Report Series 1, 1-15, 1991.

Baker, J. M., Clark, R. B., Kingston, P. F., and Jenkins, R. H.: Natural Recovery of Cold-Water Marine Environments After an Oil Spill, 13th Annual Arctic Marine Oil Spill Program Technical Seminar, Edmonton, Alberta, 1990.

Blumer, M.: Polycyclic aromatic compounds in nature, Sci. Am. (United States); 234, 35-45, 1976.

Boehm, P. D.: Aspects of the saturated hydrocarbon geochemistry of recent sediments in the Georges Bank region, Org. Geochem., 7, 11-23, 1984.

Boese, B. L., Lamberson, J. O., Swartz, R. C., Ozretich, R., and Cole, F.: Photoinduced Toxicity of PAHs and Alkylated PAHs to a Marine Infaunal Amphipod Rhepoxynius abronius, Arch. Environ. Con. Tox., 34, 235-240, doi:10.1007/s002449900311, 1998.

British Petroleum Statement on Release of OSAT Report: www.alabamagulfresponse.com/go/doc/3051/975411/, last access: 18 January 2011, 2011.

Caudill, J. and Henderson, E.: BANKING ON NATURE 2004: The Economic Benefits to Local Communities of National Wildlife Refuge Visitation, Division of Economics, US Fish and Wildlife Service, Washington, DC, 435, 2005.

Dauvin, J. C.: The fine sand Abra alba community of the bay of morlaix twenty years after the Amoco Cadiz oil spill, Mar. Pollut. Bull., 36, 669-676, 1998.

Elmgren, R., Hansson, S., Larsson, U., Sundelin, B., and Boehm, P. D.: The "Tsesis" oil spill: Acute and long-term impact on the benthos, Mar. Biol., 73, 51-65, doi:10.1007/bf00396285, 1983.

EPA: Method 8270D Semivolatile Organic Compounds by Gas Chromatography/Mass Spectrometry (GC/MS): http://www. epa.gov/osw/hazard/testmethods/sw846/pdfs/8270d.pdf, last access: 27 April 2011, 2007.
Filosa, G.: http://www.nola.com/news/gulf-oil-spill/index. ssf/2010/05/oil_booms_work_in_limited_way.html, last access: 15 October 2011, 2010.

Fowler, S. W.: Critical review of selected heavy metal and chlorinated hydrocarbon concentrations in the marine environment, Mar. Environ. Res., 29, 1-64, 1990.

Halliday, E. and Gast, R. J.: Bacteria in Beach Sands: An Emerging Challenge in Protecting Coastal Water Quality and Bather Health, Environ. Sci. Technol., 45, 370-379, doi:10.1021/es102747s, 2011.

Hayworth, J. S. and Clement, T. P.: BP's Operation Deep Clean: Is dilution the solution to beach pollution?, Environ. Sci. Technol. Viewpoints, Articles ASAP (22 April 2011), doi:10.1021/es201242k, 2011.

Hoff, R. Z. and Shigenaka, G.: Lessons From 10 Years of PostExxon Valdez Monitoring of Intertidal Shorelines, 1999 International Oil Spill Conference, Seattle, Washington, 111-117, 1999.

Hong, H., Xu, L., Zhang, L., Chen, J. C., Wong, Y. S., and Wan, T. S. M.: Special guest paper : Environmental fate and chemistry of organic pollutants in the sediment of Xiamen and Victoria Harbours, Mar. Pollut. Bull., 31, 229-236, 1995.

Keith, L. and Telliard, W.: ES\&T Special Report: Priority pollutants: I-a perspective view, Environ. Sci. Technol., 13, 416-423, doi:10.1021/es60152a601, 1979.

Kingston, P. F.: Long-term Environmental Impact of Oil Spills, Spill Sci. Technol. Bull., 7, 53-61, 2002.

Kingston, P. F., Dixon, I. M. T., Hamilton, S., and Moore, D. C.: The impact of the Braer oil spill on the macrobenthic infauna of the sediments off the Shetland Islands, Mar. Pollut. Bull., 30, 445-459, 1995.

Kingston, P. F., Dixon, I. M. T., Hamilton, S., Moore, C. G., and Moore, D. C.: Studies on the response of intertidal and subtidal marine benthic communities to the Braer oil spill, Proceedings of a Symposium held at the Royal Society of Edinburgh, 209-233, 1997.

Operational Science Advisory Team (OSAT), U. A. C.: Summary Report for Sub-Sea and Sub-Surface Oil and Dispersant Detection: Sampling and Monitoring, Paul F. Zukunft, RADM, US Coast Guard, Federal On-Scene Coordinator, Deepwater Horizon MC252, 2010.

Operational Science Advisory Team (OSAT-2), U. A. C.: Summary report for Fate and Effects of Remnant Oil in the beach Environment, Paul F. Zukunft, RADM, US Coast Guard, Federal OnScene Coordinator, Deepwater Horizon, MC252, 2011.

Ott, F. S., Harris, R. P., and O'Hara, S. C. M.: Acute and sublethal toxicity of naphthalene and three methylated derivatives to the estuarine copepod, Eurytemora affinis, Mar. Environ. Res., 1, 49-58, 1978.

Owens, E. H., Sienkiewicz, A. M., and Sergy, G. A.: Evaluation of Shoreline Cleaning Versus Natural Recovery: The Metula Spill and Komi Operations, 1999 International Oil Spill Conference, Seattle, Washington, 503-509, 1999.

Paine, R. T., Ruesink, J. L., Sun, A., Soulanille, E. L., Wonham, M. J., Harley, C. D. G., Brumbaugh, D. R., and Secord, D. L.: Trouble on oiled waters: Lessons from the Exxon Valdez oil spill, Annu. Rev. Ecol. Syst., 27, 197-235, 1996.

Page, D. S., Foster, J. C., Ficket, P. M., and Gilfillan, E. S.: LongTerm Weathering of Amoco Cadiz Oil in Soft Intertidal Sediments, 1989 International Oil Spill Conference, Seattle, Wash- 
ington, 1989.

Rakocinski, C. F., Brown, S. S., Gaston, G. R., Heard, R. W., Walker, W. W., and Summers, J. K.: Species-abundance-biomass responses by estuarine macrobenthos to sediment chemical contamination, Journal of Aquatic Ecosystem Stress and Recovery (Formerly Journal of Aquatic Ecosystem Health), 7, 201-214, doi:10.1023/a:1009931721009, 2000.

Sell, D., Conway, L., Clark, T., Picken, G. B., Baker, J. M., Dunnet, G. M., McIntyre, A. D., and Clark, R. B.: Scientific Criteria to Optimize Oil Spill Cleanup, 1995 International Oil Spill Conference, Washington, DC, 595-610, 1995.

Swartz, R. C., Cole, F. A., Lamberson, J. O., Ferraro, S. P., Schults, D. W., Deben, W. A., Lee Ii, H., and Ozretich, R. J.: Sediment toxicity, contamination and amphipod abundance at a DDT- and dieldrin-contaminated site in San Francisco Bay, Environ. Toxicol. Chem., 13, 949-962, doi:10.1002/etc.5620130614, 1994.
The Alabama Tourism Department: Economic Impact, Alabama Travel Industry, 2008, The Alabama Tourism Department, 401 Adams Avenue, Suite 126, Montgomery, AL, 36103-4927, 2009.

Uno, S., Koyama, J., Kokushi, E., Monteclaro, H., Santander, S., Cheikyula, J., Miki, S., Añasco, N., Pahila, I., Taberna, H., and Matsuoka, T.: Monitoring of PAHs and alkylated PAHs in aquatic organisms after 1 month from the Solar I oil spill off the coast of Guimaras Island, Philippines, Environ. Monit. Assess., 165, 501-515, doi:10.1007/s10661-009-0962-1, 2010.

Vandermeulen, J. H. and Singh, J. G.: ARROW Oil Spill, 1970-90: Persistence of 20-yr Weathered Bunker C Fuel Oil, Can. J. Fish. Aquat. Sci., 51, 845-855, doi:10.1139/f94-083, 1994. 